\title{
Darnios architektūros evoliucija: literatūros ir pavyzdžių apžvalga
}

\author{
Gediminas Viliūnas*, Indrẻ Gražulevičiūtė-Vileniškẻ
}

\author{
Kauno technologijos universitetas, Statybos ir architektūros fakultetas, \\ Studentu 48, Kaunas LT-51367, \\ el.paštas: g.viliunas@ktu.edu; indre.grazuleviciute@ktu.lt
}

(Gauta 2021 m. vasario mèn.; atiduota spaudai 2021 m. balandžio mèn.; prieiga internete nuo 2021 m. gegužès 11 d.)

\begin{abstract}
Anotacija
Tyrimo tikslas - atlikus mokslinės literatūros duomenų bazių ir darnios architektūros pavyzdžių apžvalgą, susisteminus darnios architektūros raidą ir problematiką pasaulyje bei situaciją Lietuvoje, per kiekvieno dešimtmečio, pradedant 1980-aisiais, progresą ir regresą ieškoti alternatyvių sprendinių šiandieninei darnios architektūros situacijai. Tyrimas igyvendinamas dviem etapais: pirmiausiai atliekama išsami kiekybinè ir kokybinè literatūros analizė ir kiekvieno dešimtmečio progreso ir regreso darnios architektūros srityje analizè raiškos, technologijų, medžiagų požiūriais, remiantis igyvendintais darnios architektūros pavyzdžiais; antrajame etape atliekama šiandieninès darnios architektūros problematikos pasaulyje bei situacijos Lietuvoje analizè ir vertinimas.
\end{abstract}

Reikšminiai žoď̆iai: architektūra; darni architektūra; darnus vystymasis.

\begin{abstract}
The aim of the research is to accomplish the review of scientific literature databases and the examples of sustainable architecture and, after systematizing the development and problems related to sustainability perspective and sustainable architecture in the world and the situation in Lithuania, to search for alternative solutions to the current situation of sustainable architecture in each decade, starting in the 1980s. The research is implemented in two stages: first, a comprehensive quantitative and qualitative literature review and analysis of progress and regression in the field of sustainable architecture for each decade in terms of expression, technology, materials are carried out based on the implemented examples of sustainable architecture; in the second stage, the analysis and assessment of today's issues of sustainable architecture in the world and the situation in Lithuania are performed.
\end{abstract}

Key words: Architecture; sustainable architecture; sustainable development

\section{Ivadas}

$\mathrm{Su}$ greitèjančia naujų projektų realizacija neatsiejamai didèja ir mūsų planetos išteklių vartojimo poreikis. Pastarasis dešimtmetis buvo kupinas naujų aukštųų technologijų proveržių: nuo unikalių statybinių medžiagų atradimų iki pirmų Marso raketos bandymų Žemèje ịgyvendinimo. Pradedama ieškoti unikalių, naujų sprendinių, kurie radikaliai keistų mūsų visų gyvenimo būdą tai, didejjančio vartotojiškumo ir žemès išteklių ribotumo pasekmè, kuri su kiekvienais metais kelia vis daugiau iššūkių. Iš vienos pusès tai labai tendencinga, kadangi planetos išteklių eksploatacijos mastas sparčiai auga, o mūsų, kaip žmonijos, siekis - rasti galimus sprendimo būdus. Tačiau reikia atsižvelgti ir ị kitą medalio pusę - visi sprendimai yra ịgyvendinami planetos išteklių sąskaita. Norèdami sumažinti pasekmes, turime ne tik kurti naujus produktus, tačiau gilintis $\mathfrak{i}$ teorinę problemos pusę ir ieškoti tinkamiausių sprendimo būdų. Vienas iš aktyviausių resursų eikvotojų statybos sektorius. Ṣ̌ dešimtmetị pastaroji sritis išgyvena savo klestejjimo laikus, todèl turime rasti būdų pakreipti ši sektorių darnaus projektavimo link. Privaloma pabrèžti - darnioje architektūroje per daug metų dèl besikeičiančios situacijos veiksnių keitėsi ịvairių problemų paskatinti sprendimo būdai, susiję su visu statybos sektoriumi. Darnios architektūros raidos sampratos, raidos (Berardi, 2013) ir tipologijos (Wines, 2002) klausimai vis dažniau sulaukia tyrèjų dèmesio, tačiau darnios architektūros dabartinei situacijai ir perspektyvoms suvokti reikalinga išsami retrospektyvi mokslinių šaltinių duomenų bazių turinio, aktualių publikacijų ir charakteringų pavyzdžių apžvalga ir analizè. 
Straipsnio tikslas - atlikti mokslinès literatūros duomenų bazių, jose referuojamų publikacijų ir darnios architektūros pavyzdžių analizę ir, remiantis ja, apžvelgti kiekvieno dešimtmečio raidą darnios architektūros srityje: nuo 1980 m., kada pirmą kartą viešai pradèta kalbèti apie klimato kaitos mažinimo priemones ir galimus darnesnès ateities planus, iki šių dienų, kada pasiekiame tikrai neblogų rezultatų: turime pakankamai technologinių ir intelektualinių resursų, kalbame apie darnios architektūros ịtaką, tačiau dèl globaliai išplètotos infrastruktūros, augančių poreikių ir vartotojiškumo, medžiagų ir energijos vartojimas ir toliau didèja.

\section{Tyrimo metodika}

Naudojantis mokslo šaltinių duomenų bazėmis (SCOPUS, Web of Science) buvo atlikta informacijos paieška tolimesniam tyrimo vystymui. Duomenų rinkimo etapas buvo vienas iš pagrindinių aspektų, nulemiančių tolimesnị tyrimą. Analizė susidèjo iš šių etapų:

- $\quad$ kiekybinès ir kokybinès literatūros analizès;

- grafinès analizès;

- darnios architektūros pavyzdžių analizès ir vertinimo.

Kiekybiné literatūros analize - tai kompleksinis duomenų rinkimas įvairiais pjūviais naudojant SCOPUS, Web of Science duomenu bazes. Analizès tikslas - suvokti kiekvieno penkmečio progresą ir regresą, mokslininkų susidomėjimą darnios architektūros tema, tematikos aktualumą per daug metų. Raktiniai paieškos žodžiai - sustainable architecture. Rezultatai vertinti pagal šiuos kriterijus: straipsnių skaičių, dominuojančius raktažodžius, pagrindinius autorius, mokslo sričių dominavimą, dominuojančius žurnalus, valstybę, kalbą. Dél nuolatos kintančių rezultatų (straipsnių papildymų) protokoluojamas prisijungimas prie sistemų. Su norimais kriterijais gauti rezultatai:

- SCOPUS duomenų bazè - 7,382 straipsnių. Prisijungimas prie sistemos - 2020-11-28 d. 00:00 val.

- Web of Science duomenų bazè - 4,358 straipsnių. Prisijungimas prie sistemos - 2020-11-28 d. 15:00 val.

Kokybine literatūros analizè buvo atliekama naudojant SCOPUS, Web of Science duomenų bazių paieškos rezultatus. Raktiniai paieškos žodžiai - sustainable architecture. Dėl galimos paieškos teksto interpretacijos rizikos, t. y. darnios architektūros sąvokos naudojamos kitose mokslo srityse, nuspręsta iš paieškos rezultatų išimti su architektūra bei statyba nesusijusias mokslo sritis, pavyzdžiui: kompiuterių mokslas, medicina, biologija. Tyrimo metodika - pasirinkti aktualiausi straipsniai perskaitomi, analizuojami, apibendrinama pagrindinè tyrimų ideja ir pateikiama chronologine tvarka, siekiant atskleisti idejų raidą.

Grafine analize - tai grafinis analizuotų duomenų bazių duomenų sisteminis atvaizdavimas. SCOPUS ir Web of Science duomenu bazių paieškos rezultatai konvertuojami i bibliografini formatą (RIS), kuris „sutraukia” paieškos rezultatus ị vieną tekstinị dokumentą. Vèliau duomenys keliami ị CiteSpace bibliometrinès analizès programą, kuria analizuojama visa informacija ir suformuojami grafikai. Tokiu metodu siekiama perteikti dideli informacijos kieki viename paveiksle: tai leidžia ne tik lengviau suvokti duomenis, bet ir greičiau atrasti daugiausiai ar mažiausiai tyrinètas sritis ar klausimus.

Darnios architektūros pavyzdžių analizè ir vertinimas - AIA COTE (Amerikos architektų instituto Aplinkos komiteto) sudaromų darnių pastatų dešimtukų nuo 1997 iki 2020 metų apžvalga. Išskiriami du charakteringi darnios architektūros pavyzdžiai kiekvieniems metams laikotarpiu nuo 1997 iki 2020 m. Aprašomi pagrindiniai darnūs sprendimai / elementai, dominuojantys kiekvienais analizuotais metais. Atlikta analizè leido suprasti technologinị progresą, vyraujančias tendencijas.

109 
Taip pat toks informacijos sisteminimo principas leidžia patikrinti kiekybinès ir kokybinès literatūros analizès rezultatus ir ịvertinti, ar mokslinių tyrimų akiratyje vyrauja tos pačios tendencijos / siūlomos taikyti priemonès, kaip ir praktiniame iqgyvendinime.

\section{Rezultatai}

Kiekybinė literatūros šaltinių analizė. Tyrimo pradžioje, siekiant susisteminti didelị kiekị duomenų, pradedamas kiekybinis duomenų rinkimas iš SCOPUS duomenų bazès (1 lentelè).

1 lentelèje matomi duomenys suskirstyti i 16 stulpelių ir išskiriamas bendras straipsnių skaičius - 7382. Nurodoma data ir pagal metus konkrečiam laikotarpiui priskiriamas: straipsnių skaičius, Lietuvoje parašyti straipsniai, dominuojantis raktažodis, daugiausiai publikacijų paskelbęs autorius, daugiausiai publikacijų paskelbęs lietuvių autorius, dominuojanti mokslo sritis, Lietuvoje dominuojanti mokslo sritis, pagrindinè kalba, dominuojanti institucija, dominuojanti Lietuvos institucija, dominuojanti valstybè, populiariausias publikacijos būdas, populiariausias Lietuvos autorių publikacijos būdas, populiariausias žurnalas / konferencija, populiariausias žurnalas / konferencija Lietuvos publikacijoms.

1 lentelès suvestinès duomenys parodè didelị progresinị šuolị 1993-1997 m. ir 1998-2002 m. laikotarpiais. Nuo 31 iki 109 straipsnių išaugis rodo, kad tai lūžio periodas, kuris diktavo aukštą pasaulio mokslininkų susidomėjimą darnios architektūros tematika. Verta pabrèžti, kad pasaulinio susidomejjimo darnios architektūros tema šiuo laikotarpiu nepasiekè Lietuvos, t. y. šiais periodais Lietuvos autoriai darnios architektūros tema nebuvo publikavę tyrimų SCOPUS duomenų bazès ištekliuose, tačiau 1998-2002 m. ir 2003-2007 m. atsiranda ir lietuvių mokslininkų publikacijų. Pirmoji lietuvių publikacija šioje duomenų bazèje tyrinejjama tema - P. Grecevičius (Klaipejdos universitetas) parašytas straipsnis.

Minèti penkmečiai taip pat pasižymėjo pasaulinio susidomėjimo šuoliu: nuo 109 iki 697 straipsnių. Pastovus augimas vyksta iki šių dienų, todèl galime daryti prielaidą, kad tokia tendencija vyraus ir toliau: palyginę paskutinị 4 metų laikotarpi 2018-2021 m. (2102 straipsniai) su 20132017 m. penkmečiu (2688 straipsniai) matome nedideli sumažejjimą, tačiau reikia ịvertinti, kad paskutinis periodas yra nepilnas -4 metai (vietoje 5). Grafiškai pavaizduoti tyrimo rezultatai pateikti diagramoje (1 pav.).

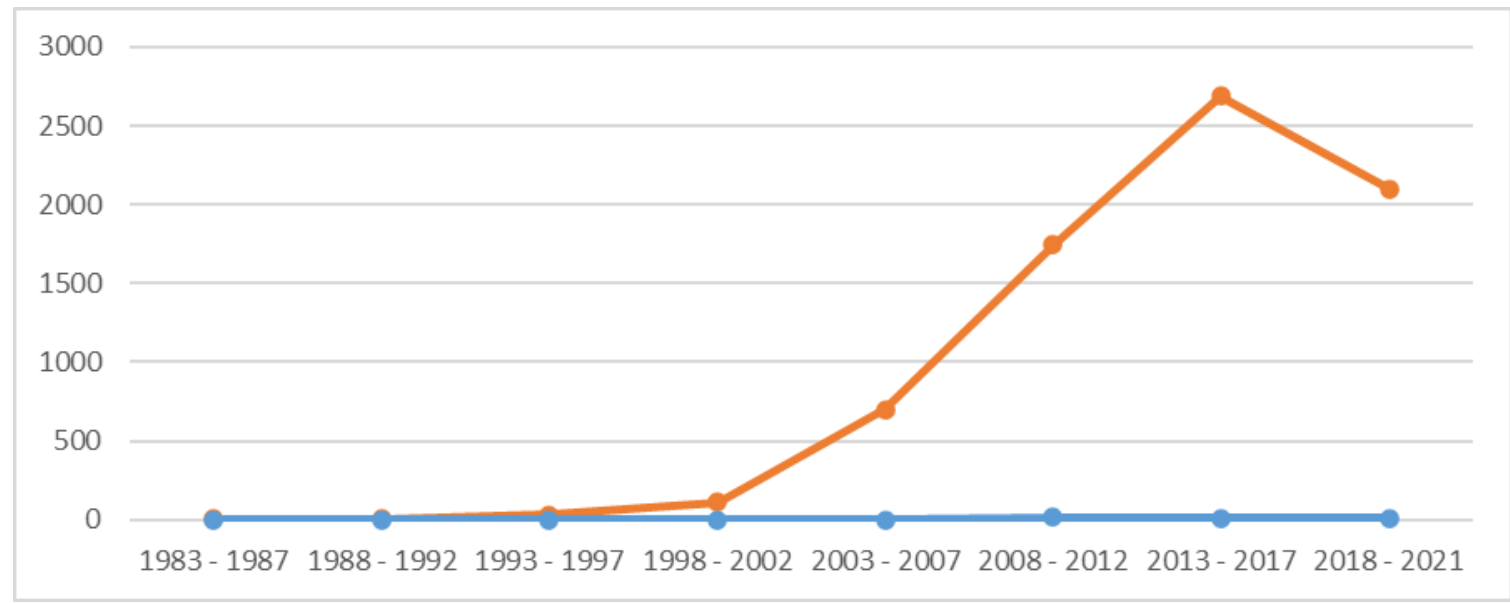

1 pav. SCOPUS duomenų bazès duomenų diagrama lyginanti Lietuvos mokslininkų indèlị (mèlyna spalva) su pasauliniu progresu (ornažinė spalva) tyrinèjant darnios architektūros klausimus. Sudaryta autorių

Fig. 1. Diagram of SCOPUS database data diagram comparing the worldwide progress (orange) and the progress of Lithuanian researchers (blue) analyzing the questions of sustainable architecture. Graph by the authors 
1 lentelè. SCOPUS duomenų bazès paieškos rezultatų suvestinè. Sudarė autoriai

Table 1. Summary of SCOPUS database search results. Table by the authors

\begin{tabular}{|c|c|c|c|c|c|c|c|c|c|c|c|c|c|c|c|c|}
\hline $\begin{array}{c}\text { Bendras } \\
\text { straipsniu } \\
\text { skaicius }\end{array}$ & Data & $\begin{array}{c}\text { Straipsniu } \\
\text { skaicius }\end{array}$ & $\begin{array}{c}\text { Lietuvoje } \\
\text { parasyti } \\
\text { straipsniai }\end{array}$ & $\begin{array}{c}\text { Dominuojantis } \\
\text { raktazododis }\end{array}$ & \begin{tabular}{|c|} 
Pagrindinis \\
autorius
\end{tabular} & $\begin{array}{c}\text { Dominuojantis } \\
\text { Lietuvių autorius }\end{array}$ & $\begin{array}{c}\text { Dominuojanti } \\
\text { mokslo sritis }\end{array}$ & $\begin{array}{c}\text { Lietuvoje } \\
\text { dominuojanti } \\
\text { mokslo sritis }\end{array}$ & $\begin{array}{l}\text { Pagrindinè } \\
\text { kalba }\end{array}$ & $\begin{array}{c}\text { Dominuojanti } \\
\text { institucija }\end{array}$ & \begin{tabular}{|c|} 
Didžiausia \\
Lietuvos \\
institucija
\end{tabular} & $\begin{array}{c}\text { Dominuojanti } \\
\text { valstybè }\end{array}$ & $\begin{array}{c}\text { Populiariausias } \\
\text { publikacijos } \\
\text { būdas }\end{array}$ & \begin{tabular}{|c|} 
Populiariausias \\
Lietuvių \\
publikacijos būdas
\end{tabular} & $\begin{array}{c}\text { Populiariausias } \\
\text { žrunalask konferencija }\end{array}$ & 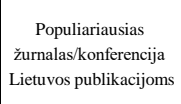 \\
\hline \multicolumn{17}{|l|}{7382} \\
\hline & $\begin{array}{r}1983- \\
1987\end{array}$ & 6 & 0 & Architektūra (3) & \begin{tabular}{|l} 
Levine, R.S. \\
(2)
\end{tabular} & 0 & Inžnerija (6) & 0 & Anglu (6) & \begin{tabular}{|l|} 
University of \\
Kentucky (2)
\end{tabular} & 0 & Nenustatyta (6) & Konferencija (6) & 0 & $\begin{array}{l}\text { Wescon Conference } \\
\text { Record }\end{array}$ & 0 \\
\hline & $\begin{array}{r}1988- \\
1992\end{array}$ & 5 & 0 & Architektüra (2) & \begin{tabular}{|c|} 
Glass, C.J. \\
(1)
\end{tabular} & 0 & Inžnerija (3) & 0 & Anglu (5) & $\begin{array}{c}\text { Boeing } \\
\text { Aerospace and } \\
\text { Electronic (1) }\end{array}$ & 0 & $\operatorname{JAV}(3)$ & Žurnalas (3) & 0 & $\begin{array}{l}\text { Journal of Architectural } \\
\text { Education }\end{array}$ & 0 \\
\hline & $\begin{array}{r}1993- \\
1997\end{array}$ & 31 & 0 & Architektüra (7) & wu, J.S. (2) & 0 & Inžinerija (16) & 0 & Anglu (31) & $\begin{array}{l}\text { National } \\
\text { Central } \\
\text { University } \\
\text { Taiwan (2) }\end{array}$ & 0 & $\begin{array}{c}\text { Jungtiné } \\
\text { Kuralystè (5) }\end{array}$ & Žurnalas (23) & 0 & $\begin{array}{c}\text { Corporate } \\
\text { Environmental Strategy }\end{array}$ & 0 \\
\hline & $\begin{array}{l}1998- \\
2002\end{array}$ & 109 & 0 & \begin{tabular}{|c|} 
Darnus \\
vystymasis (43)
\end{tabular} & $\begin{array}{c}\text { Farmer, G. } \\
\text { (2) }\end{array}$ & 0 & Inžinerija (61) & 0 & Anglu (96) & \begin{tabular}{|c} 
Newcastle \\
University (3)
\end{tabular} & 0 & $\operatorname{JAV}(26)$ & Žurnalas (83) & 0 & Places & 0 \\
\hline & $\begin{array}{r}2003- \\
2007\end{array}$ & 697 & 1 & \begin{tabular}{|c|} 
Darnus \\
vystymasis (381)
\end{tabular} & \begin{tabular}{|c|} 
De Weck, O. \\
$(6)$
\end{tabular} & $\begin{array}{c}\text { Grecevicius, P. } \\
\text { (1) }\end{array}$ & Inžinerija (452) & $\begin{array}{l}\text { Socialinis } \\
\text { mokslas (1) }\end{array}$ & \begin{tabular}{|l|} 
Anglu (682) \\
\end{tabular} & $\begin{array}{c}\text { American } \\
\text { Institute of } \\
\text { Aeronautics and } \\
\text { Astronautics, } \\
\text { Inc. (19) }\end{array}$ & \begin{tabular}{|c} 
Klaipeda \\
University (1)
\end{tabular} & JAV (208) & $\begin{array}{c}\text { Konferencija } \\
(392)\end{array}$ & Žurnalas (1) & $\begin{array}{l}\text { International Journal of } \\
\text { Engineering Education }\end{array}$ & \begin{tabular}{|l} 
Town Planning And \\
Architecture
\end{tabular} \\
\hline & $\begin{array}{r}2008- \\
2012\end{array}$ & 1746 & 16 & \begin{tabular}{|c|} 
Darnus \\
vystymasis (899)
\end{tabular} & Zeiler, W. (9) & Jakaitis, J. (3) & Inžinerija (900) & $\begin{array}{l}\text { Socialinis } \\
\text { mokslas (7) }\end{array}$ & Angly (1700) & $\begin{array}{c}\text { Xian University } \\
\text { of Architecture } \\
\text { and Technology } \\
\text { (25) }\end{array}$ & $\begin{array}{c}\text { Vilniaus } \\
\text { Gedimino } \\
\text { Technikos } \\
\text { Universitetas } \\
\text { (8) }\end{array}$ & $\mathrm{JAV}(345)$ & $\begin{array}{c}\text { Konferencija } \\
(907)\end{array}$ & Žurnalas (16) & $\begin{array}{c}\text { World Applied Sciences } \\
\text { Journal }\end{array}$ & \begin{tabular}{|c|} 
Town Planning And \\
Architecture
\end{tabular} \\
\hline & $\begin{array}{r}2013- \\
2017\end{array}$ & 2688 & 8 & $\begin{array}{c}\text { Darnus } \\
\text { vystymasis } \\
\text { (1279) }\end{array}$ & $\begin{array}{l}\text { Mileto, C. } \\
\text { (14) }\end{array}$ & $\begin{array}{c}\text { Antuchevičiene, } \\
\text { J. (1) }\end{array}$ & $\begin{array}{l}\text { Inžninerija } \\
(1666)\end{array}$ & Inžninerija (6) & Angly (2628) & $\begin{array}{c}\text { Universitat } \\
\text { Politecnica de } \\
\text { València (52) }\end{array}$ & $\begin{array}{c}\text { Villiaus } \\
\text { Gedimino } \\
\text { Technikos } \\
\text { Universitetas } \\
\text { (6) }\end{array}$ & $\operatorname{JAV}(370)$ & $\begin{array}{c}\text { Konferencija } \\
(1137)\end{array}$ & Žurnalas (6) & \begin{tabular}{|} 
Xi'an Jianzhu Keji \\
Daxue Xuebao/Journal \\
of Xi'an University of \\
Architecture and \\
Technology
\end{tabular} & $\begin{array}{c}\text { Journal of Architecture } \\
\text { and Urbanism }\end{array}$ \\
\hline & $\begin{array}{r}2018- \\
2021\end{array}$ & 2102 & 11 & $\begin{array}{c}\text { Darnus } \\
\text { vystymasis (858) }\end{array}$ & \begin{tabular}{|c|} 
Garcia- \\
Soriano, L. \\
(7)
\end{tabular} & $\begin{array}{c}\text { Zavadskas, E.K. } \\
\text { (4) }\end{array}$ & $\begin{array}{c}\text { Inžninerija } \\
(1067)\end{array}$ & $\begin{array}{l}\text { Socialinis } \\
\text { mokslas (7) }\end{array}$ & Angly (2044) & $\begin{array}{c}\text { Universitat } \\
\text { Politernica de } \\
\text { Valencia (34) }\end{array}$ & $\begin{array}{c}\text { Villiaus } \\
\text { Gedimino } \\
\text { Technikos } \\
\text { Universitetas } \\
\text { (6) }\end{array}$ & JAV (218) & Žurnalas (1181) & Žurnalas (8) & \begin{tabular}{|c} 
Journal of Materials \\
Science and Technology
\end{tabular} & $\begin{array}{c}\text { Journal of Sustainable } \\
\text { Architecture and Civil } \\
\text { Engineering }\end{array}$ \\
\hline
\end{tabular}


Analogiškai SCOPUS duomenų bazès analizei atliekamas tyrimas ir su kitos duomenų bazès - Web of Science - duomenimis (2 lentelè).

2 lentelè. Web of Science duomenų bazès paieškos rezultatų suvestinè. Sudare autoriai

Table 2. Summary of Web of Science database search results. Table by the authors

\begin{tabular}{|c|c|c|c|c|c|c|c|c|c|c|c|c|c|c|c|c|}
\hline $\begin{array}{l}\text { Bendras } \\
\text { straipsniu } \\
\text { skaičiss }\end{array}$ & Data & $\begin{array}{c}\text { Straipsniu } \\
\text { skaičius }\end{array}$ & $\begin{array}{c}\text { Lietuvoje } \\
\text { parašyti } \\
\text { straipsniai }\end{array}$ & $\begin{array}{c}\text { Dominuojantis } \\
\text { raktažodis }\end{array}$ & \begin{tabular}{|c|} 
Pagrindinis \\
autorius
\end{tabular} & \begin{tabular}{|c|} 
Dominuojantis \\
Lietuvių autorius
\end{tabular} & $\begin{array}{c}\text { Dominuojanti } \\
\text { mokslo sritis }\end{array}$ & \begin{tabular}{|c|} 
Lietuvoje \\
dominuojanti \\
mokslo sritis
\end{tabular} & \begin{tabular}{|c}
$\begin{array}{c}\text { Pagrindinè } \\
\text { kalba }\end{array}$ \\
all
\end{tabular} & $\begin{array}{c}\text { Dominuojanti } \\
\text { institucija }\end{array}$ & $\begin{array}{c}\text { Didžiausia } \\
\text { Lietuvos } \\
\text { institucija }\end{array}$ & $\begin{array}{c}\text { Dominuojanti } \\
\text { valstybè }\end{array}$ & $\begin{array}{l}\text { Populiariausias } \\
\text { publikacijos } \\
\text { būdas }\end{array}$ & $\begin{array}{c}\text { Populiariausias } \\
\text { Lietuviu } \\
\text { publikacijos būdas }\end{array}$ & $\begin{array}{c}\text { Populiariausias } \\
\text { žrnalas/konferencija }\end{array}$ & \begin{tabular}{|c} 
Populiariausias \\
žurnalas/konferencija \\
Lietuvos publikacijoms
\end{tabular} \\
\hline \multicolumn{17}{|l|}{4358} \\
\hline & $\begin{array}{r}1990- \\
1994\end{array}$ & 13 & 0 & Architektūra (5) & Blake J. (1) & 0 & Architektūra (5) & 0 & Anglu (13) & \begin{tabular}{|c|} 
Auburn \\
university (1)
\end{tabular} & 0 & $\mathrm{JAV}(4)$ & Žurnalas (6) & 0 & Architecture & 0 \\
\hline & $\begin{array}{r}1995- \\
1999\end{array}$ & 52 & 0 & Energetika (22) & Jain K. (2) & 0 & Energetika (22) & 0 & Anglu (52) & \begin{tabular}{|c|} 
School Of \\
Planning \\
Architecture \\
New Delhi (2)
\end{tabular} & 0 & JAV (13) & Žurnalas (26) & 0 & $\begin{array}{l}\text { Journal Of Urban } \\
\text { Technology }\end{array}$ & 0 \\
\hline & $\begin{array}{r}2000- \\
2004\end{array}$ & 117 & 0 & Architektữa (32) & Oktay D. (3) & 0 & Inžnerija (45) & 0 & Angly (114) & \begin{tabular}{|c|} 
Eastern \\
Mediterranean \\
University (3) \\
\end{tabular} & 0 & JAV (24) & Konferencija (60) & 0 & Energy And Buildings & 0 \\
\hline & $\begin{array}{r}2005- \\
2009\end{array}$ & 346 & 6 & Architektưra (97) & \begin{tabular}{|c|} 
Lehmann S. \\
(5)
\end{tabular} & \begin{tabular}{|c} 
Dzemydiene D. \\
(2)
\end{tabular} & $\begin{array}{c}\text { Aplinkos } \\
\text { mokslai (108) }\end{array}$ & $\begin{array}{c}\text { Verslo } \\
\text { ekonomika (3) }\end{array}$ & Anglų (332) & \begin{tabular}{|c} 
Pennsylvania \\
Commonwealth \\
System Of \\
Higher \\
Edcation \\
Pcshe (7)
\end{tabular} & \begin{tabular}{|c|} 
Vilnius \\
University (3)
\end{tabular} & $\operatorname{JAV}(74)$ & $\begin{array}{c}\text { Konferencija } \\
\text { (194) }\end{array}$ & Žurnalas (4) & $\begin{array}{l}\text { Journal Of Green } \\
\text { Building }\end{array}$ & $\begin{array}{c}\text { Technological And } \\
\text { Economic Development } \\
\text { Of Economy }\end{array}$ \\
\hline & $\begin{array}{r}2010- \\
2014\end{array}$ & 1090 & 14 & $\begin{array}{l}\text { Architektüra } \\
\text { (245) }\end{array}$ & \begin{tabular}{|l} 
Gambardella \\
C. (18)
\end{tabular} & Naryydas A. (4) & Inžinerija (451) & Inžinerija (12) & Anglu (1060) & $\begin{array}{c}\text { Universita } \\
\text { Della } \\
\text { Campania } \\
\text { Vanvitelli (14) }\end{array}$ & $\begin{array}{c}\text { Kaunas } \\
\text { University Of } \\
\text { Technology } \\
(6)\end{array}$ & $\begin{array}{c}\text { Kinijos } \\
\text { Liaudies } \\
\text { Respublika } \\
(162)\end{array}$ & $\begin{array}{c}\text { Konferencija } \\
(691)\end{array}$ & Konferencija (10) & Applied Energy & $\begin{array}{c}\text { Journal Of Civil } \\
\text { Engineering And } \\
\text { Management }\end{array}$ \\
\hline & $\begin{array}{r}2015- \\
2019\end{array}$ & 2294 & 8 & \begin{tabular}{|c} 
"Žaliosios" \\
technologijos \\
(416)
\end{tabular} & \begin{tabular}{|l} 
Gambardella \\
C. (12)
\end{tabular} & \begin{tabular}{|c|} 
Zavadskas Ek. \\
(3)
\end{tabular} & Inžinerija (681) & $\begin{array}{l}\text { Aplinkos } \\
\text { mokslai (4) }\end{array}$ & Anglu (2167) & \begin{tabular}{|l|} 
Islamic Azad \\
University (58)
\end{tabular} & \begin{tabular}{|c} 
Vilnius \\
Gedimino \\
Technikos \\
Universitetas \\
(5)
\end{tabular} & JAV (258) & Žurnalas (1308) & Žurnalas (6) & Scientific Reports & Problemy Ekorozwoju \\
\hline & $\begin{array}{r}2020- \\
2021\end{array}$ & 446 & 2 & \begin{tabular}{|c} 
"Žaliosios" \\
technologijos \\
(135)
\end{tabular} & Kim Y. (5) & Bliudzius R. (1) & $\begin{array}{c}\text { Mokslo } \\
\text { technologijos } \\
\text { bei kitos temos } \\
\text { (156) }\end{array}$ & \begin{tabular}{|c|} 
Mokslo \\
technologijos \\
bei kitos temos \\
(1)
\end{tabular} & Anglu (434) & \begin{tabular}{|c} 
Chinese \\
Academy Of \\
Sciences (8)
\end{tabular} & $\begin{array}{l}\text { Frederick } \\
\text { Univ (1) }\end{array}$ & \begin{tabular}{|c|} 
Kinijos \\
Liaudies \\
Respublika (73)
\end{tabular} & Žurnalas (375) & Žurnalas (1) & $\begin{array}{l}\text { International Journal of } \\
\text { Engineering And } \\
\text { Geosciences }\end{array}$ & Zemdirbyste-Agricultur \\
\hline
\end{tabular}


2 lentelèje matomi duomenys suskirstyti i 16 stulpelių ir išskiriamas bendras straipsnių skaičius - 4358. Nurodoma data ir pagal metus konkrečiam laikotarpiui priskiriamas: straipsniu skaičius, Lietuvoje parašyti straipsniai, dominuojantis raktažodis, daugiausiai publikacijų paskelbęs autorius, daugiausiai publikacijų paskelbęs lietuvių autorius, dominuojanti mokslo sritis, Lietuvoje dominuojanti mokslo sritis, pagrindinè kalba, dominuojanti institucija, dominuojanti Lietuvos institucija, dominuojanti valstybė, populiariausias publikacijos būdas, populiariausias lietuvių autorių publikacijos būdas, populiariausias žurnalas / konferencija, populiariausias žurnalas / konferencija Lietuvos publikacijoms.

2 lentelès suvestinès duomenys parodė stiprų progresinị šuoli 2000-2004 m. ir 2005-2009 m. laikotarpiais. Nuo 117 iki 346 straipsnių išaugis rodo, kad tai kertinio lūžio periodas, atskleidžiantis išaugusį pasaulio mokslininkų susidomėjimą darnios architektūros tematika. Verta pabrèžti, kad šia pasaulinio susidomejjimo sulaukusia tema Lietuvos autoriai Web of Science duomenų bazès ištekliuose pradejo skelbti publikacijas 2005-2009 m. periodu. Ši penkmeti parašyti 6 Lietuvos institucijų autorių straipsniai darnios architektūros tematika.

2005-2009 m. ir 2010-2014 m. laikotarpiais matomas proveržis pasauliniame kontekste nuo 346 iki 1090 straipsnių. Pastovus augimas vyksta iki šių dienų: per 2015-2019 m. laikotarpi paskelbti 2294 straipsniai. I Web of Science duomenų bazę patenka itin aukšto lygio šaltiniai ir straipsniai, turintys didelị indèli i pasaulinę mokslo raidą. Pabrezžiama, kad šioje duomenų bazèje straipsniai darnios architektūros klausimais buvo publikuojami tik nuo 1990 m. Siekiant grafiškai pavaizduoti tyrimo rezultatus, buvo sudaryta diagrama (2 pav.).



2 pav. WOS (Web of Science) duomenų bazès duomenų diagrama lyginanti Lietuvos mokslininkų indèlị (mèlyna spalva) su pasauliniu progresu (ornažinè spalva) tyrinejjant darnios architektūros klausimus. Sudaryta autorių Fig. 2. Diagram of WOS (Web of Science) database data comparing the worldwide progress (orange) and the progres of Lithuanian researchers (blue) analyzing the questions of sustainable architecture. Graph by the authors

Atlikus kiekybinę duomenų analizę, galima daryti išvadą, kad nors Lietuvos indèlis globaliu mastu nėra didelis, tačiau mūsų šalyje darnios architektūros klausimai taip pat sulaukia dèmesio. Ši analizès stadija parodė kertinius lūžių etapus darnios architektūros tyrimuose, leido pamatyti Lietuvos indèlị, universitetus, kurie vykdo tyrimus aplinkai svarbiais klausimais.

Kokybinè literatūros šaltinių analizè. Kokybinès literatūros analizès etapas būtinas, norint suprasti autorių straipsniuose keliamus klausimus analizuotu laikotarpiu tiek SCOPUS, tiek Web of Science duomenų bazèse referuojamose publikacijose. Publikacijos pristatomos ir aptariamos chronologine tvarka, siekiant atskleisti idèjų nagrinèjamoje srityje raidą.

SCOPUS duomenu bazès teikiamų publikacijų kokybinè analizè. R. S Levine (1984) konferencijos pranešimo medžiagoje diskutavo apie saulės sprendinius architektūrai ir pabrèžè, kad 
daugelis savybių, būdingų darnios architektūros judèjimui, yra visiškai priešingos dominuojantiems stiliams šiuolaikinèje architektūroje. Tas pats autorius R. S. Levine (1984) pristatè „New Hope“ kooperatinès bendruomenès, kuri bus aprūpinta maistu ir energija, Kentukio valstijos kaimo vietovejje, koncepciją. S. Downen ir kt. (1985) konferencijos pranešime diskutavo apie statybos procesą ir ryši su dizaino sprendiniais; keliami klausimai, kaip derinti žemès ūkį, architektūrą ir ekologiją, kad būtų galima pasiekti tvaresni gyvavimą, pristatomi pastatai kurie pasižymi savo unikaliu, išbaigtu dizainu.

J. Motloch (1990) straipsniu siekiama pritaikyti sistemini požiūri valdant miestų kraštovaizdį bei projektavimą ir pereiti nuo tūrio (materialaus objekto) iki mažesnio ir abstraktesnio vieneto, kada kalbama apie žmogaus komfortą ir psichologinę savijautą. D. Lock (1991) straipsniu akcentavo žaliuosius miestus bei jų ịtaką aplinkai, apžvelgè darnios urbanistikos minties raidą. Paliečiama ir 1991 m. Didžiosios Britanijos situacija ekologiškų miestų aspektu. Rašoma, kad pati žaliojo miesto koncepcija yra ne kas kitas, kaip vietos pertvarkymas, kuris gali valdyti miesto augimą, nedarant matomos ịtakos miesto architektūrinei išraiškai. W. G. Sturges (1992) publikacijoje paliete itin svarbų klausimą, kuris šiuo metu vis aktyviau kvestionuojamas: medžio, kaip statybinès medžiagos naudojimą. Pastaraisiais dešimtmečiais matome pastovų šios medžiagos naudojimo augimą.

P. R. Diprose ir G. Robertson (1996) publikacijoje pastebima, kad projektavimo gairèse pripažistamos platesnès žmogaus ir ekosistemos perspektyvos ir apgalvotas medžiagų ir energijos išteklių naudojimas per visą pastato eksploatacijos laikotarpi sukuria darnų prisitaikymą prie klimato. S. Kim (1996) publikacijoje akcentavo išlaikytą kritinę poziciją prieš ịprastą Vakarų architektūrinès estetikos požiūrị pristatant Rytų Azijos žmogaus sukurtos aplinkos vaizdą. Diskusijoje akcentuojami trys estetinio svarstymo taškai: aplinkos, santykių ir gyvenimo estetika. Siūloma, kad architektūra turètų būti suvokiama kaip viena iš aplinkosaugos sudedamujų dalių, o ne kaip savarankiškas objektas, nepriklausomas nuo kitų dedamujų. G. Lueben (1997) nagrinèjo strateginị mąstymą ir konkrečius veiksmus, skirtus ịgyvendinti architektūros kompanijos integruoto tvaraus dizaino tikslą.

M. M. AboulNaga ir Y. H. Elsheshtawy (2001) straipsnio tikslas - ištirti darnumo pokyčius Jungtiniuose Arabų Emyratuose (JAE), naudojant vertinimo ịrankį, kuris matuoja pastatų efektyvumą atsižvelgiant ị jų darnumą. Šiuo tyrimu bandoma: parengti išsamų darnumo apibrèžimą, atitinkantị JAE poreikius, klasifikuoti darnios statybos praktiką tarptautiniu ir regioniniu lygmeniu, vertinti pastatų efektyvumą JAE, nustatyti darnios architektūros gaires. H. M. Edge ir R. Pearson (2001) paskelbtoje publikacijoje akcentuojamas besikeičiantis vietos suvokimas ir architektūrinių simbolių naudojimas vertinant ir planuojant aplinką. Straipsnyje teigiama, kad taisyklès, siekusios išsaugoti ir skatinti kurti liaudies motyvus pabrěžiančias formas (architektūrinę išraišką) Didžiosios Britanijos kaimo vietovèse, tam tikra prasme tiesiogiai prieštarauja faktinei liaudies kalbai, t. y. išraiškai. G. Farmer ir S. C. Guy (2002) tyrimu pabrěžta, kad šiuo metu dominuoja technokratiškas požiūris aplinkos pokyčių klausimais. Publikacijos pradžioje kalbama apie bendrą požiūrị, iš kurio kilo ideja skatinti naudoti natūralios ventiliacijos koncepciją, vèliau pereinama prie konkuruojančios vėdinimo vizijos.

D. J. Cowan (2007) straipsnyje nagrinejjama darnumo sąvoka bakalauro studijų projekto, igyvendinto teritorijoje už Džogjakartos ribų, Indonezijoje, kontekste. Projekte dalyvavo studentai iš Purdue inžinerijos ir technologijos mokyklos. Projektas buvo orientuotas ị regiono architektūrą ir darnią statybą. Tais pačiais metais publikuotas S. Gruber (2007) tyrimas, orientuotas i Kinijos kultūros paveldą ir besikeičiančius požiūrius ị jị. Bandoma ieškoti būdų, kaip išsaugoti kultūros vertybes bei ịtraukti jas ị darnios plètros procesą. 
B. GaBriela ir T. Cerkez (2012) nagrinèja švietimo vaidmeni ir jo reikšmę formuojantis kritiškam ir sąmoningam architektūros vartotojui. Akivaizdu, kad švietimo strategijų, susijusių su supančiomis erdvèmis ir aplinka, kūrimas tampa pagrindiniu prioritetu. Individas privalo suprasti darnaus vystymosi koncepciją, todèl verta apmąstyti, kaip švietimo programos skatina kritišką ir atsakingą požiūrị i supančią aplinką, kaip pastaroji formuoja darnaus erdvinio ir aplinkos vystymo sampratas, kartu suteikiant didelę laisvę architektūros raiškai. Z. Zamani ir kt. (2012) tyrime pabrèžiama, kad statybos sektorius, kaip vienas pagrindinių energijos vartotojų, privalo laikytis tvarumo principų. Vienas iš pateikiamų sprendimų straipsnyje nagrinejjamoje klimato zonoje vidinių kiemų įrengimas. Taip pat verta paminėti ir A. Ziemel̦niece (2012) publikaciją, kurioje akcentuojama, kad kultūros paveldas yra daug potencialo turinti sritis, galinti užtikrinanti kokybišką žmogaus gyvenimą bei darnų vystymąsi.

B. Bajçinovci (2017) publikacijoje pasyvaus bioklimatinio projektavimo principai siejami su darniu aplinkai dizainu, regiono mikroklimatu, šilumine energija, erdvine, vaizdine, akustine ir oro kokybe. S. Oliveira ir E. Marco (2012) publikacijoje pateikiami duomenys apie architektūros ir aplinkos inžinerijos projektavimo studijas, kuriose mokomoji veikla yra glaudžiai susijusi su inžinerijos tyrimais ir eksperimentais. Publikacijoje nagrinèjami iššūkiai ir galimybès, su kuriomis studentai susiduria dirbdami prie dizaino projekto, bandoma pakeisti nusistovèjusi požiūri i architektūrą ir aplinkosaugą. I. I. Chatzikonstantinou ir S. Sariyildiz (2017) straipsnyje pateikia skaičiavimo sistemą, skirtą projekte taikytų sprendimų taisymui. Siūloma sistema remiasi automatinio asociacinio mokymosi modeliais, kurie induktyviai mokosi sąsajų tarp projektavimo ypatybių ir efektyvaus projekto.

T. Ahmad ir kt. (2021) publikacijoje analizuojami kriterijai, lemiantys darnios architektūros projektų sėkmę. Tyrime naudojamas kokybinès analizès metodas. Buvo atlikti interviu penkiose šalyse su ekspertais, dirbančiais žaliųų pastatų srityje. Nustatyta 17 sėkmės kriterijų ir 39 subkriterijai, skirti nustatyti, ar naudotojai patenkinti šių pastatų gyvavimu, ar toks statinys kuria papildomą vertę. Teoriškai kriterijų tyrimas suteikia gilesnị supratimą apie pastato projekto sèkmę, ypač darnių pastatų atveju.

Web of Science duomenu bazès teikiamu publikacijų kokybinè analizè. A. Wright (1994) analizavo, kaip suderinama projektavimo praktika su mažai energijos naudojančių pastatų statyba ir vadinamujų „tvarių strategijų“ vystymu. Straipsnyje pristatyta projektavimo metodika akcentuojant, kiek galima sutaupyti energijos ir sumažinti atliekų kiekį. Svarbu suvokti, kad nors 20-30\% šias energijos sąnaudas galima sumažinti naudojant naujausias technologijos, maždaug 70-80 \% galimų prieinamų patobulinimų galima pasiekti projektiniais, pastato orientacijos sprendimais. Sh. Kendall (1999) tyrime rašoma apie ,atviro pastato" viziją: autoriaus teigè, kad tokie pastatai bus ekonomiškai efektyvūs, kupini naujų technologijų, taip pat leis keisti individo darbo organizavimą (jei kalbama apie biuro pastatus), žmonių gyvenimo stilių. Taip pat verta paminèti ir F. M. van Eijnatten ir L. W. L. Simonse (1999) tyrimą darnaus kūrybingumo ir produktų vystymo, įtraukiant darnaus vystymosi mokslo profesionalus, tema.

Y. Zhu ir B. R. Lin (2004) straipsnyje pabrěžè, kad būtina plètoti tvarias statybų technologijas, taikytinas konkretiems klimato regionams ir ekonominèms sąlygoms. Straipsnyje remiantis dabartinès statybų pramonès plètros situacija ir pastatų energijos suvartojimo Kinijoje mastu analizuojami tvaraus būsto ir miesto statybų reikalavimai, charakteristikos, standartai ir rekomenduojami techniniai sprendimai, tvarus projektavimas ir statyba, kurie sustiprina bendradarbiavimą tarp mokslininkų, projektuotojų ir statybų sektoriaus. W. Sheate ir W. R. Sheate (2004) tyrime nagrinejjo keturių scenarijų, skatinančių tvaresnę oro uostų plètrą, igyvendinamumą, daugiausia demesio skiriant oro uosto terminalo pastato projektavimui ir antžeminiam transportui. D. Kelbaugh (2004) publikacijoje išreiškè nerimą dèl intelektualinių ir pragmatiškų iššūkių 
architektūros sričiai ir architektūros mokymui. Publikacijoje teigiama, kad egzistuoja bent septynios projektavimo klaidos, kurios ịvairiais būdais sužlugdo gerają profesinę praktiką ir studiju metodologiją daugumoje architektūros mokyklų. Kai kurios klaidos yra lengvai valdomos, tačiau kitos problemos ne taip lengvai sprendžiamos, nes tai lemia technologijos, globalizacija ir kapitalas.

D. Hoeferlin ir K. Seidman (2009) publikacija sieke diskusijos apie „The Franz“ pastatą Naujajame Orleane ir aplinkinès miesto teritorijos atgaivinimą. Kalbama apie pastato bei vietos istoriją ir galimą raidą: galimybę išsaugoti dali kaimynystès istorijos, taip pat paskatinti vystytis vietinius verslus. Verta paminèti ir O. A. Sonaiya ir O. Dincyurek (2009) straipsni, kuriame siekiama ieškoti taškų, galinčių sujungti dvi, iš pažiūros skirtingas, pozicijas. Tyrimas pagrịstas jorubų, Vakarų Afrikos gyventojų, apklausa apie tradicinę architektūrą. Mažèjant pastarojo stiliaus naudojimui, projektavimo specialistai ima skeptiškai vertinti toki projektavimo metodą. Jorubų kultūros likimas priklauso nuo sąmoningo bandymo ją suderinti su šiuolaikinių žmonių poreikiais, gyvenimo būdu ir pasaulèžiūra.

M. Juvancic ir kt. (2014) publikuotame tyrime apie architektūros edukaciją išsamiai nagrinèjami komunikaciniai gebejjimai, remiamasi idèja, kad i plačiają visuomenę turètų būti kreipiamasi tiek prisitaikant prie jos sugebejimų, tiek papildomai mokant individus papildomų gebėjimų. Eksperimentas prototipinę architektūrinę edukacinę sąsają išbando pradinėse mokyklose ir stebimas interaktyvumo lygio poveiki mokymosi rezultatams. Y. Wu ir kt. (2020) straipsniu siekiama atnaujinti susidomèjimą I. McHarg's idejjomis, įtraukiant jas i Kinijos miestų kraštovaizdžio architektūros sprendimus.

Straipsnių ir konferencijų pranešimų kokybinè analizė atskleidė platų ir įvairiapusi darnios architektūros tyrimų lauką ir šių tyrimų raidą. Pirmaisiais analizuotais penkmečiais (1983-1994) mokslininkai problemą tyrinejjo daugiau iš teorinès perspektyvos: gilinamasi ị esamus objektus, išteklius bei stengiamasi pritaikyti, analizuoti jų panaudojimo galimybes darnumo srityje. Vèlesniais periodais (1995-2009) liečiamas švietimo klausimas, pradedama naudotis informacinių technologijų suteikiamomis priemonèmis, taip pat atsigręžiama i kultūros paveldo vertybių išsaugojimą. Pastarajị dešimtmetị (2010-2021) problemos sprendžiamos pasitelkiant edukacines sąsajas, gilinamasi $\mathfrak{i}$ visuomenès psichologiją, tai pat naudojamos aukštosios technologijos medžiagų tyrimuose ir skaičiavimuose. Šj laikmetị persipina tiek teoriniai, aprašomieji, tiek aukštosiomis technologijomis grịsti tyrimai.

Grafinė analizė. Norint suprasti dažniausiai autorių akcentuojamas su darnumu susijusias problemines temas, būtinas tiek SCOPUS, tiek Web of Science kokybinių ir kiekybinių duomenų sisteminimas. Grafinès analizès tikslas suglaudinti kokybinius ir kiekybinius duomenis i vieną vektorini paveikslèlį, kuris atvaizduotų dažniausiai liečiamas darnios architektūros temas.

Brěžiniai sudaryti naudojant CiteSpace programinę įrangą bei SCOPUS ir Web of Science duomenų bazių bibliografinius duomenis. 3 ir 4 pav. identifikuoja du pagrindinius aspektus: tamsiai žali apskritimai - dažniausiai naudojamus raktinius žodžius su darnia architektūra susijusiuose straipsniuose, o šviesiai žali apskritimai - valstybes, kurioje publikuota daugiausiai straipsnių darnios architektūros klausimais. Šviesiai žalio apskritimo dydis priklauso nuo publikacijų skaičiaus konkrečioje šalyje: kuo didesnis skritulys, tuo daugiau paskelbta publikacijų. Tamsiai žalio apskritimo dydis priklauso nuo minimo raktinio žodžio straipsniuose skaičiaus: kuo didesnis skritulys, tuo didesniame straipsnių skaičiuje specifinis raktinis žodis minimas. Valstybès išdėstytos brèžinio perimetre, raktiniai žodžiai - centre. Nagrinètose duomenų bazèse Junginès Amerikos Valstijos aiškiai dominuoja pagal publikuojamus darnios architektūros tyrimus, taip pat galima išskirti Kiniją. Dažniausiai vartojami raktažodžiai: darnus vystymasis, darnumas, architektūrinis projektavimas, architektūra. 


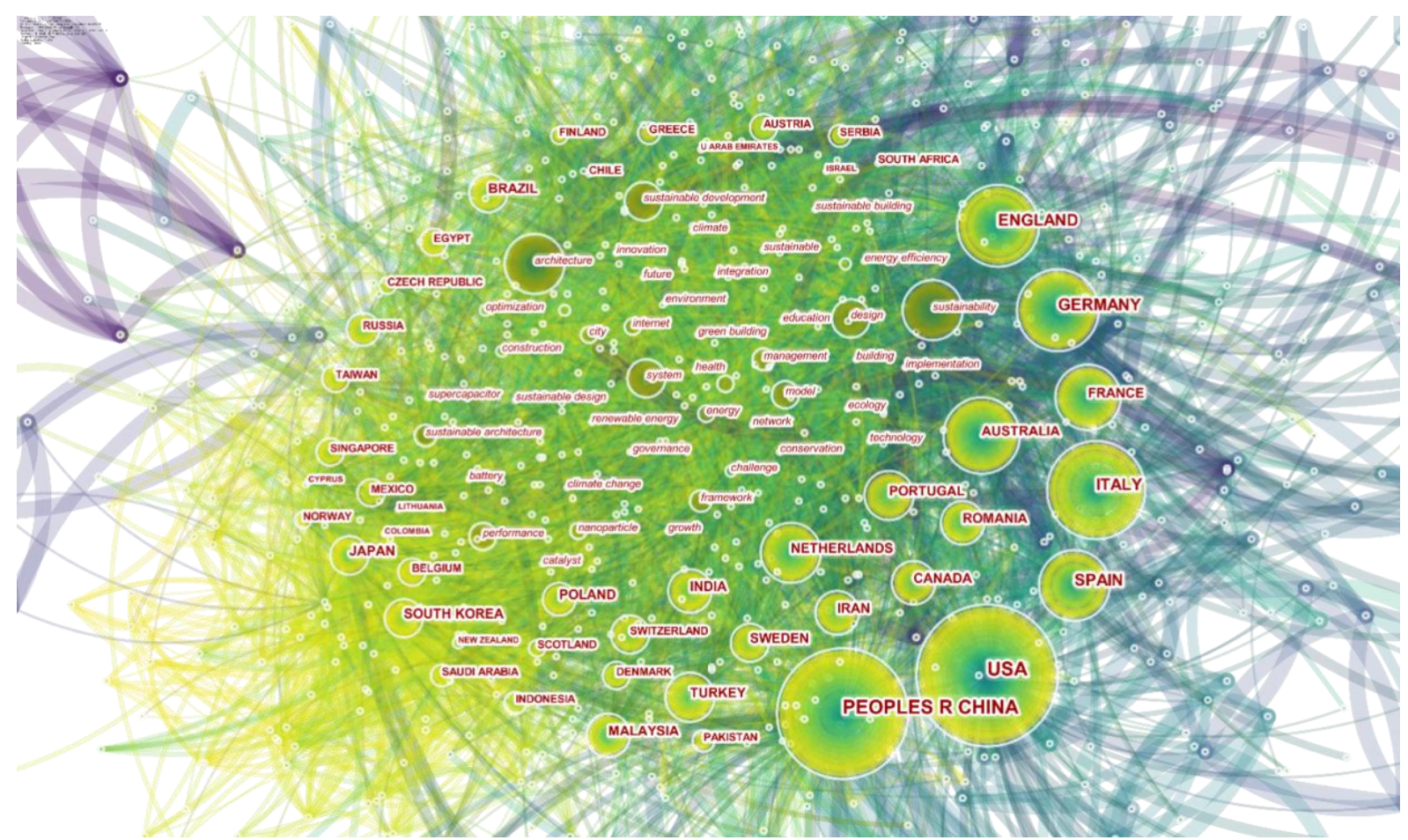

3 pav. Web of Science duomenų bazès paieškos duomenų grafinè analizè. Sudaryta autoriu naudojant CiteSpace programą

Fig. 3. Web of Science database search data graphical analysis. Graph by the authors using CiteSpace software



4 pav. SCOPUS duomenų bazėd paieškos duomenų grafinè analizè. Sudaryta autorių naudojant naudojant CiteSpace programą

Fig. 4. SCOPUS database search data graphical analysis. Graph by the authors using CiteSpace software

* Kontaktinis asmuo / Corresponding author 
Darnios architektūros pavyzdžių analizė ir vertinimas. AIA COTE (Amerikos architektų instituto Aplinkos komiteto) kiekvienais metais sudaromu darnios architektūros pastatu dešimtuku apžvalgoje išskiriama po du charakteringus darnios architektūros pavyzdžius kiekvienais metais - nuo 1997 iki 2000 m. - ir aprašomi pagrindiniai darnūs sprendimai / elementai. Atlikta analizė leido suprasti technologini progresą, vyraujančias tendencijas. Taip pat toks informacijos sisteminimo principas leidžia patikrinti kiekybinės ir kokybinės literatūros analizės rezultatus: ar moksliniu tyrimu akiratyje vyrauja tos pačios tendencijos / siūlomos taikyti priemonès kaip ir praktiniame igyvendinime. Atlikus tyrimą iš tiesų pastebèta atitikimų tarp mokslininkų analizuojamų darnių sprendimų ir realizuotų darnios architektūros projektų. Pavyzdžiui, viename iš apžvelgtu SCOPUS duomenu bazèje 2008-2012 m. penkmeti paskelbtu straipsniu rašoma apie kultūros paveldo tausojima bei vertinimą. AIA COTE vienas iš nugalètojų būtent $2012 \mathrm{~m}$. akcentavo esamo konstruktyvo išsaugojimą, galima priežastis - paveldo objektų tausojimas.



5 pav. AIA COTE sudaromų darnių pastatų dešimtukų chronologinė nugalètojų seka - laiko juosta. Sudaryta autorių remiantis www.aiatopten.org duomenimis Fig. 5. The time line analysis of AIA COTE top ten sustainable buildings winners. Scheme by the authors based on www.aiatopten.org data 
Atlikus pavyzdžių analizę, pastebèta, kad tendencijos šiame konkurse atspindèjo to meto technologinę pažangą. Pirmieji laimètojai (nuo 1997 m. iki 2001 m.) pabrèžè patalpų šilumos valdymą, natūralų apšvietimą, pasyvius fasadus, esamo konstruktyvo išlaikymą, šiltnamio efektą sukeliančių dujų emisijų mažinimą, laisvesnio išplanavimo taikymą, perdirbamų medžiagų panaudojimą, laisvesnę tūrio išraišką, didesnę kompozicinę ịvairovę, inovatyvių (to meto) technologijų naudojimą. Šiuo laikmečiu architektūros raiškoje dominavo monumentalumas, statika. Nuo $2002 \mathrm{~m}$. iki $2006 \mathrm{~m}$. nugalètojų projektuose pabrèžiamas jau minèto stiklo kaip medžiagos, suteikiančios natūralaus apšvietimo galimybę, technologinė panauda. Akcentuojama natūrali ventiliacija, atviras planas, iš dalies laisvų formų fasadai, energijos taupymas, tamsaus paros meto išnaudojimas patalpų vėdinimui, langų funkcionalumas. $2007 \mathrm{~m}$. - $2011 \mathrm{~m}$. laikotarpiu projektuotojai integruoja išmaniuosius langus, tamsaus paros meto sistemas, kurios védina patalpas, atsinaujinančią energiją, patalpų planavimą atsižvelgiant ì pasaulio šalis, geoterminị šildymą, ypač mažo šilumos laidumo insuliacijos naudojimą, aukšto energetinio efektyvumo boilerių panaudojimą, esamo konstruktyvo efektyvų panaudojimą keičiant pastato funkciją, perdirbtas medžiagas, taip pat jau ankščiau minètą „laisvų" formų fasadą. $2012 \mathrm{~m}$. - $2016 \mathrm{~m}$. pateikiami projektai, pasižymintys jau minètu esamos struktūros išlaikymu (senų konstrukcijų panaudojimu), saulès elementais, žaliaisiais stogais, aukštos energinès klasės šviesos diodų apšvietimo naudojimu, pasyvaus namo savybėmis. 2017 m. - 2020 m. naudojamos anksčiau minètos technologijos, tačiau atsigręžiama ir į ekosistemų talpumą, mažesnių struktūrų panaudos galimybes.

Lietuvoje kol kas pasigendama darnios architektūros populiarinimo ir plètros skatinimo. Organizuojamose veiklose dažnu atveju tik paminima, kad darnūs sprendimai galimi. Galima paminèti renginị, skatinusị darnios architektūros projektų viešinimą bei diskusiją apie tai - tai Lietuvos nekilnojamojo turto plètros asociacijos LNTPA organizuotas konkursas „Už darnią plètrą".

Darnios architektūros iššūkiai. Remiantis kiekybine ir kokybine literatūros analize ir pavyzdžių analize, išskiriami svarbiausi su darnia architektūra susiję iššūkiai.

Švietimo darnios architektūros klausimais būtinybè. S. Oliveira ir E. Marco (2017) teigimu, mokomoji veikla yra glaudžiai susijusi su inžinerijos tyrimais ir eksperimentais darnumo srityje. Literatūros apžvalgoje minètas ne vienas tyrimas švietimo darnios architektūros klausimais tema. Grafinè literatūros analizė atskleidė mažą Lietuvos ịsitraukimą ì darnios architektūros tyrimus, palyginti su panašaus dydžio valstybėmis. Švietimo įstaigos turètų aktyviau skatinti studentus ir mokslininkus įsitraukti į šią tyrimų sritị. Lietuvoje kol kas pasigendama darnios architektūros populiarinimo ir plètros skatinimo, todèl būtinas formalus ir neformalus švietimas darnios architektūros klausimais.

Aukštuju technologiju naudojimas įvertinant turimus išteklius. Literatūros analizè atskleidè tendencijas gilintis i naujus procesus, naudojantis naujausiais technologiniais įrankiais sukurti naujus modelius, tačiau verta pabréžti ir jau turimų išteklių panaudojimą, gilintis ị semantinę vietos prasmę, kaip tai darè J. Motloch (1990). Svarbu suprasti, kad architektūros darnumas nèra vien tik žali stogai, ar saulès elementai. Reikia ịvertinti, kad darnumas užkoduotas ne tik technologijose, bet ir vietos specifikoje, socialiniuose, kultūriniuose kontekstuose.

Kultūros paveldo išsaugojimas ir panaudojimas. Kultūros paveldo išsaugojimas ir panaudojimas yra vienas iš darnios architektūros iššūkių. Atlikus tyrimą, rasta nemažai publikacijų šia tema, AIA COTE darnių pastatų konkurse paveldo išsaugojimas taip pat yra reikšmingas kriterijus. Tačiau iki šiol praktikoje pirmenybė dažnai teikiama naujai statybai. Pastatų pakartotinio panaudojimo skatinimas ir jo visapusès naudos atskleidimas turètų tapti vienu iš darnios architektūros prioritetų. 
Darnumo kriteriju akcentavimas organizuojamuose architektūros konkursuose. Vadovaujantis išsivysčiusių ir darnaus vystymosi srityje pažengusių šalių organizuojamų konkursų praktika, būtina ịtraukti darnios architektūros kriterijus, kaip vieną iš esminių architektūros konkursų sąlygų.

\section{Išvados}

1. Kiekybinè literatūros analizè atskleidè nuolat augantị susidomèjimą su darnia architektūra susijusiais klausimais ir didèjantị šios temos aktualumą. Per visą analizuotą laikotarpi mokslinių publikacijų tiriamu klausimu nuolat daugejo: nuo kelių ar keliolikos 1980-aisiais ir 1990-aisiais metais iki pastaruoju metu kasmet paskelbiamų šimtų publikacijų.

2. Kokybinè literatūros analizè atskleidè, kad tyrimų progresas darnios architektūros srityje priklauso nuo laikmečio technologinès pažangos ir sprendžiamų iššūkių. Buvo pastebėta, kad 1983-1994 paskelbtose analizuotose publikacijose darnios architektūros klausimais mokslininkai problemą tyrinèjo daugiau iš teorinès perspektyvos, skelbè pavyzdžių aprašymus ir analizes, vèlesniais periodais liečiamas švietimo klausimas, pradedama naudotis informacinių technologijų suteikiamomis priemonèmis, taip pat atsigręžiama ị kultūros paveldo vertybių išsaugojimą. Pastarajj dešimtmeti problemos sprendžiamos pasitelkiant edukacines sąsajas, gilinamasi ị visuomenès psichologiją, tai pat naudojamos aukštosios technologijos medžiagų tyrimuose ir skaičiavimuose.

3. Grafinè literatūros analizė parodè mažą Lietuvos ịsitraukimą ị darnios architektūros tyrimus, palyginti su panašaus dydžio valstybèmis. Šiuo metu darnios architektūros tyrimų srityje pirmaujančios valstybès - Jungtinès Amerikos Valstijos ir Kinija.

4. Pasaulyje darnios architektūros projektų konkursai rengiami nuo paskutiniojo praejjusio amžiaus dešimtmečio. Vienas tokių konkursų - AIA COTE (Amerikos architektų instituto Aplinkos komiteto) nuo 1997 m. kiekvienais metais sudaromas darnios architektūros pastatu dešimtukas. Šio konkurso nugalètojais pripažinti projektai atspindi darnios architektūros technologinių ir estetinių tendencijų raidą. Pastebèta, kad pirmaisiais dešimtmečiais šio konkurso projektų darnios architektūros tendencijos glaudžiai siejosi su su to meto mokslo ir technologijų raida - projektuose bandoma integruoti naujausius to meto sprendimus, tačiau mažiau dèmesio skiriama tradicinèms technologijoms ir paveldui. Vèlesnių laikotarpių projektai įvairesni, mažiau tiesiogiai atspindi technologijų pažangą, atsiskleidžia įvairiapusis architektų kūrybingumas, matomas dèmesys paveldui. Tokio pobūdžio konkursų organizavimas Lietuvoje taip pat galètų paskatinti pažangą darnios architektūros srityje.

5. Apibendrinus tyrimo rezultatus, galima teigti, kad architektūros darnumas neapsiriboja vien tik technologiniais aspektais ir gali būti susijęs su vietos ir kraštovaizdžio tapatumu, socialiniu ir kultūriniu kontekstu, vietinėmis tradicijomis ir kitais veiksniais. Svarbiausi tyrime išskirti darnios architektūros iššūkiai: švietimo darnios architektūros klausimais būtinybė, aukštujų technologijų naudojimas ịvertinant turimus išteklius, kultūros paveldo išsaugojimas ir panaudojimas, darnumo kriterijų akcentavimas organizuojamuose architektūros konkursuose.

Padėka. Šis tyrimas atliktas pagal 2014-2020 m. ES fondų investicijų veiksmų programos priemonės Nr. 09.3.3-LMT-K-712 „Mokslininkų, kitų tyrëjų, studentų mokslinès kompetencijos ugdymas per praktinę mokslinę veiklą“ veiklą „Studentų gebejjimų vykdyti MTEP (meno tyrimų) veiklas ugdymas“. Projekto pavadinimas: „Darnios architektūros evoliucija. Galimi sprendimo būdai šiandienai”. Sutarties NR. 09.3.3-LMT-K-712-22-0030. 


\section{Literatūra}

1. AboulNaga, M. M., \& Elsheshtawy, Y. H. (2001). Environmental sustainability assessment of buildings in hot climates: The case of the UAE. Renewable Energy, 24(3-4), P. 553-563. doi:10.1016/S0960-1481(01)00041-6

2. AIA Committee on the Environment. AIA Committee on the Environment Top Ten Projects. (2020). Prieiga per internetą: https://www.aiatopten.org/

3. Ahmad, T., Aibinu, A. A., Stephan, A. (2021). Green building success criteria: Interpretive qualitative approach. Journal of Architectural Engineering, 27(1). Prieiga per internetą: https://ascelibrary.org/doi/pdf/10.1061/\%28ASCE\%29AE.1943-5568.0000448

4. Bajçinovci, B. (2017). Achieving thermal comfort and sustainable urban development in accordance with the principles of bioclimatic architecture: A case study of Ulcinj (Montenegro). Quaestiones Geographicae 36(4), P. 131-140. doi:10.1515/quageo-2017-0041

5. Berardi, U. (2013). Clarifying the new interpretations of the concept of sustainable building. Sustainable Cities and Society, 8, P. 72-78.

6. Chatzikonstantinou, I., Sariyildiz, I. S. (2017). Addressing design preferences via auto-associative connectionist models: application in sustainable architectural façade design. Automation in Construction 83, P. 108-120. doi:10.1016/j.autcon.2017.08.007

7. CiteSpace programine įranga. (2020). Prieiga per internetą: http://cluster.cis.drexel.edu/ cchen/citespace/

8. Cowan, D. J. (2007). Building sustainable architecture and livelihoods in Indonesia: an international education. International Journal of Engineering Education, 23(6), P. 1126-1132.

9. Diprose, P. R., Robertson, G. (1996). Towards a fourth skin? Sustainability and double-envelope buildings. Renewable Energy, 8(1-4), P. 169-172.

10. Downen, S., Koehn, S., Pierce, D., Rantis, D. (1985). Model sustainable farmstead and staff housing at the Meadowcreek project, Fox, Arkansas. Journal of the College of Architecture, Planning and Design Kansas state University 8, P. 205-208.

11. van Eijnatten, F. M., Simonse, L. W. (1999). Organizing for creativity, quality and speed in product creation processes. Quality and Reliability Engineering International, 15(6) P. 411-416.

12. Edge, H. M., Pearson, R. (2001). Vernacular architectural form and the planning paradox: a study of actual and perceived rural building tradition. Journal of Architectural and Planning Research 18(2), P. 91-109.

13. Farmer, G., Guy, S. (2002). Conditional constructions: Environmental discourses on natural ventilation. International Journal of Environmental Technology and Management 2(1-3), P. 187-199. doi:10.1504/ijetm.2002.000786

14. GaBriela, B., Cerkez, T. (2012). Promotion of a viable art education through architecture. Arte, Individuo y Sociedad 24(2), P. 251-268. doi:10.5209/rev-ARIS.2012.v24.n2.39030

15. Gruber, S. (2007). Protecting China's cultural heritage sites in times of rapid change: current developments, practice and law. Asia Pacific Journal of Environmental Law 10(3-4), P. 253-301.

16. Hoeferlin, D. J. (2009). The Franz Building: a strong advocation for adaptive re-use in post-Katrina New Orleans. Journal of Green Building 4(1), P. 23-40.

17. Juvancic, M., Hocevar, M., Zupancic, T. (2014). Improving communication and changing attitudes in architectural practices: digital architectural education tools for non-experts. Open House International 39(4):91100

18. Kaszewski, A. L., Sheate, W. R. (2004). Enhancing the sustainability of airport developments. Sustainable development 12(4), P. 183-199.

19. Kelbaugh, D. (2004). Seven fallacies in architectural culture. Journal of Architectural Education 58(1), P. 6668.

20. Kendall, S. (1999). Open building: an approach to sustainable architecture. Journal of Urban Technology 6(3), P. $1-16$.

21. Kim, S. (1996). Aesthetics of field, relationship, and life: an East Asian viewpoint of environmental aesthetics. Acta Polytechnica Scandinavica, Civil Engineering and Building Construction Series 105, P. 51-55.

22. Levine, R. S. (1984). Form vs. Substance: the necessity for a sustainable architecture. Prieiga per internetą: www.scopus.com.

23. Levine, R. S. (1984). New Hope: a sustainable community. Prieiga per internetą: www.scopus.com.

24. LNTPA konkursas „Už darnią plètrą“. (2020). Prieiga per internetą: http://lntpa.lt/darnios-pletrosakademija/konkursai-uz-darnia-pletra-ir-darni-aplinka/

25. Lock, D. (1991). The propaganda of the built environment. RSA Journal 139(5419), P. 455-466. 
26. Lueben, G. (1997). Hellmuth, Obata \& Kassabaum: Establishing a sustainable design practice in architecture and engineering. Corporate Environmental Strategy, 4(3), 24-31.

27. Motloch, J. (1990). Placemaking: urban landscape system management. Systems Research 7(4), P. $273-285$. doi:10.1002/sres.3850070406

28. Oliveira, S., Marco, E. (2017). Preventing or inventing? understanding the effects of non-prescriptive design briefs. International Journal of Technology and Design Education 27(4), P. 549-561. doi:10.1007/s10798-0169369-9

29. Sonaiya, O. A., Dincyurek, O. (2009). Tradition and modernism in Yoruba architecture: bridging the chasm. Open House International 4(34), P. 74-81.

30. Sturges, W. G. (1992). An exploration of the relationships between houses and forests in American history. Journal of Architectural Education, 46(2), P. 66-75. doi:10.1080/10464883.1992.10734539

31. Wines, J. (2002). Green architecture. Taschen, Koln, P. 240.

32. Wright, A. (1994). Technology and tradition. Renewable Energy. Prieiga per internetą: www.scopus.com.

33. Wu, Y., Swain, R. E., Jiang, N., Qiao, M., Wang, H., Bai, J., ... \& Wu, J. Z. (2020). Design with nature and ecocity design. Ecosystem Health and Sustainability, 6(1), 1781549.

34. Zamani, Z., Taleghani, M., Hoseini, S. B. (2012). Courtyards as solutions in green architecture to reduce environmental pollution. Energy Education Science and Technology Part A: Energy Science and Research, 1(30), P. 385-396.

35. Ziemelniece, A. (2012). Contextual searches of the architectural space and green structure of bauska old town. Journal of Architecture and Urbanism 36(4), P. 298-303. doi:10.3846/20297955.2012.752935

36. Zhu, Y., Lin, B. (2004). Sustainable housing and urban construction in China. Energy and Buildings 36(12), P. 1287-1297.

\section{Evolution of Sustainable Architecture: Review of Literature and Examples}

(Received in February, 2021; Accepted in April, 2021; Available Online from 11 ${ }^{\text {th }}$ of May, 2021)

\section{Summary}

The construction sector is one of the most active consumers of resources, thus it is important to minimize the consumerism of this sector and to search for the ways of designing and constructing in a more sustainable way. The aim of the research is to accomplish the review of scientific literature databases and sustainable architecture examples and to search for the solutions to the current situation of sustainable architecture through literature and examples' analysis in each decade, starting from the 1980s. The research is implemented in two stages: first, a comprehensive quantitative and qualitative literature review and analysis of progress in the field of sustainable architecture for each decade in terms of expression, technology, materials are carried out based on the implemented examples of sustainable architecture; in the second stage, the analysis and assessment of today's issues of sustainable architecture in the world and the situation in Lithuania are performed.

Quantitative analysis of literature has revealed a growing interest in the issues related to sustainable architecture and the growing relevance of this topic. Qualitative analysis of the literature revealed that the progress of research in the field of sustainable architecture (from descriptive analysis to the latest technological aspects) depends on the prevailing technological progress and challenges at that time. Graphical analysis of literature identified low involvement of Lithuania in the research of sustainable architecture compared to countries of similar size. Competitions for sustainable architecture projects in developed countries have been held since the last decade of the last century. The organization of such competitions in Lithuania could also encourage progress in this area. The most important challenges of sustainable architecture were highlighted in the study: the need for education on sustainable architecture, the use of high technologies together with valorization of available resources, the preservation and use of cultural heritage, the emphasis on sustainability criteria in organized architectural competitions. 